\title{
The Vegetation Structure (Background) on the Territory of Planned Coal Mine (Irkutsk Region)
}

\author{
Alexander P. Sizykh \\ Siberian Institute of Plant Physiology and Biochemistry of RAS SB, Irkutsk, Russia \\ Email: alexander.sizykh@gmail.com
}

How to cite this paper: Sizykh, A.P. (2017) The Vegetation Structure (Background) on the Territory of Planned Coal Mine (Irkutsk Region). Open Access Library Journal, 4: e3849.

https://doi.org/10.4236/oalib.1103849

Received: July 26, 2017

Accepted: August 13, 2017

Published: August 16, 2017

Copyright (c) 2017 by author and Open Access Library Inc.

This work is licensed under the Creative Commons Attribution International License (CC BY 4.0).

http://creativecommons.org/licenses/by/4.0/

\begin{abstract}
Within investigations for project and establishing of a coal mine, preliminary survey aimed to revealing of modern state of vegetation at the territory of establishing of projected coal mine was performed. The information of the structure of phytocenoses modern state can be a reference position for the assessment of a possible impact of technical activities on the state of phytocenoses around the territory of the mine establishment.
\end{abstract}

\section{Subject Areas}

Biogeography

\section{Keywords}

Vegetation Structure, Planned Coal Mine, Irkutsk Region

\section{Introduction}

The aim of studies is to find out the modern structure of vegetation on the territory related to the category of potential different exploitation forms; in this case, this is an organization of a coal mine as a first stage of a coal yield in the whole region. Technogenic impact onto the vegetation at coal mine exploration, besides a complete destruction of soil and vegetation cover, can influence negatively the phytocenoses of the adjacent surroundings of the explored territory in such forms as roads construction, warehouses building and accumulating of gasoline and related materials for machinery and creating of fire-dangerous situations during the mine exploitation. Due to this fact, it is necessary to determine the most optimal sites for establishment of the infrastructure of the planned 
mine to minimize its impact onto the vegetation, mainly to keep basic forests (subtaiga) with emphasis to use secondary (small-leaf) forests and cenoses of reconstruction series. It is as well very important to limit maximally (or to exclude) the use of the territory of water protection zones of water flows in the area

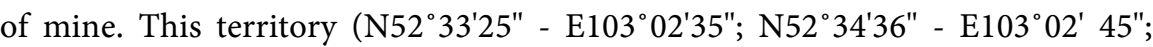

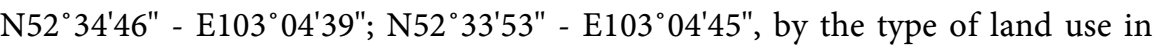
the studied area, according to the map of land use of the south of the East Siberia [1], belongs to the category of exploited land (Figure 1).

According to the performed ecological zoning [2], the studied territory is included to the zone of atmospheric impact of low danger (up to $1 \%$, zone B) with plain-valley pre-mointain type of climate at regulated intensive type of the territory development.

According to the correlational ecological-phytocenotic [3] map, the background vegetation of the studied area and of its surrounding area consists of subtaiga, south-taiga, somewhere low-mountain forests containing pine (Pinus sylvestris L.) and larch (Larix sibirica Ledeb.)-pine, mainly with cowberry (Vaccinium vitis-idea L.) and cowberry-motley grasses and grasses; sometimes there are steppificated forests with fragments of meadow steppes of higher productivity.

The Atlas of Irkutsk Region [4] according to the vegetation map ([4], p. 42) for the studied area and its surroundings shows the characteristic forests. They contain pine (Pinus sylvestris L.) and larch (Larix sibirica Ledeb.)-pine cowberry (Vaccinium vitis-idea L.) - grasses at graded slopes everywhere; this fact correlates with data on the structure of phytocenoses shown on the maps of the south of the East Siberia [5] characteristic for the surroundings of the studied area.

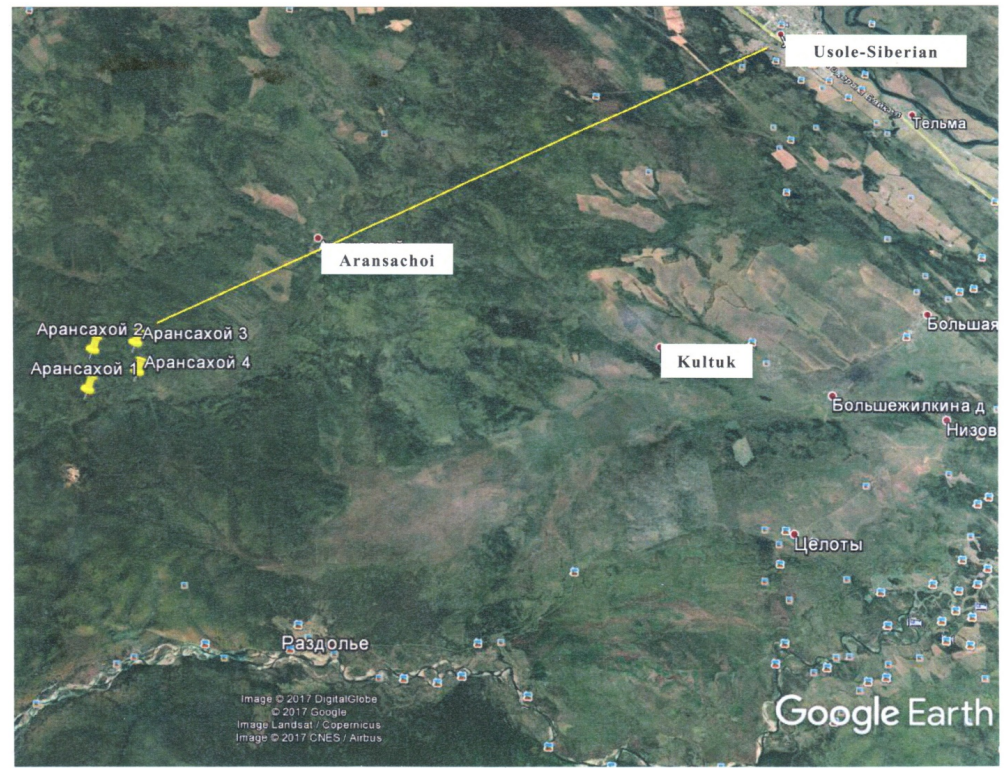

Figure 1. Area of study-marked by yellow color (Irkutsk region). The picture of the studied territory is borrowed from Google Earth site for better obviousness and spatial orientation. 


\section{Methods}

Main research method is geobotanical survey together with the analysis of fund materials (forestry and agriculture) by vegetation state during different years of land use in the whole region. As the materials of studies are background ones (for survey), the revealing of plants indicating cenoses and setting of main (characteristic) plants species are sufficient at this studies stage.

\section{Results}

Due to performed field studies, it is stated that basic vegetation of the area are pine (Pinus sylvestris L.) and birch (Betula pendula Roth) - pine (Pinus sylvestris L.) with larch (Larix sibirica Ledeb.) forests of subtaiga type jointly with second birch forests including light-coniferous trees species (Pinus sylvestris L., Larix sibirica Ledeb.). Such communities form at moderatelt cold, long-time frosted sod-podzol soils on plain-hillside sites of the studied territory itself and of its surroundings [6]. The pictures present typical communities of the studied area (see Figures 2-4).

The undergrowth of such communities is often dominated by pine (Pinus sylvestris L.) and larch (Larix sibirica Ledeb.), there is a large fraction of birch

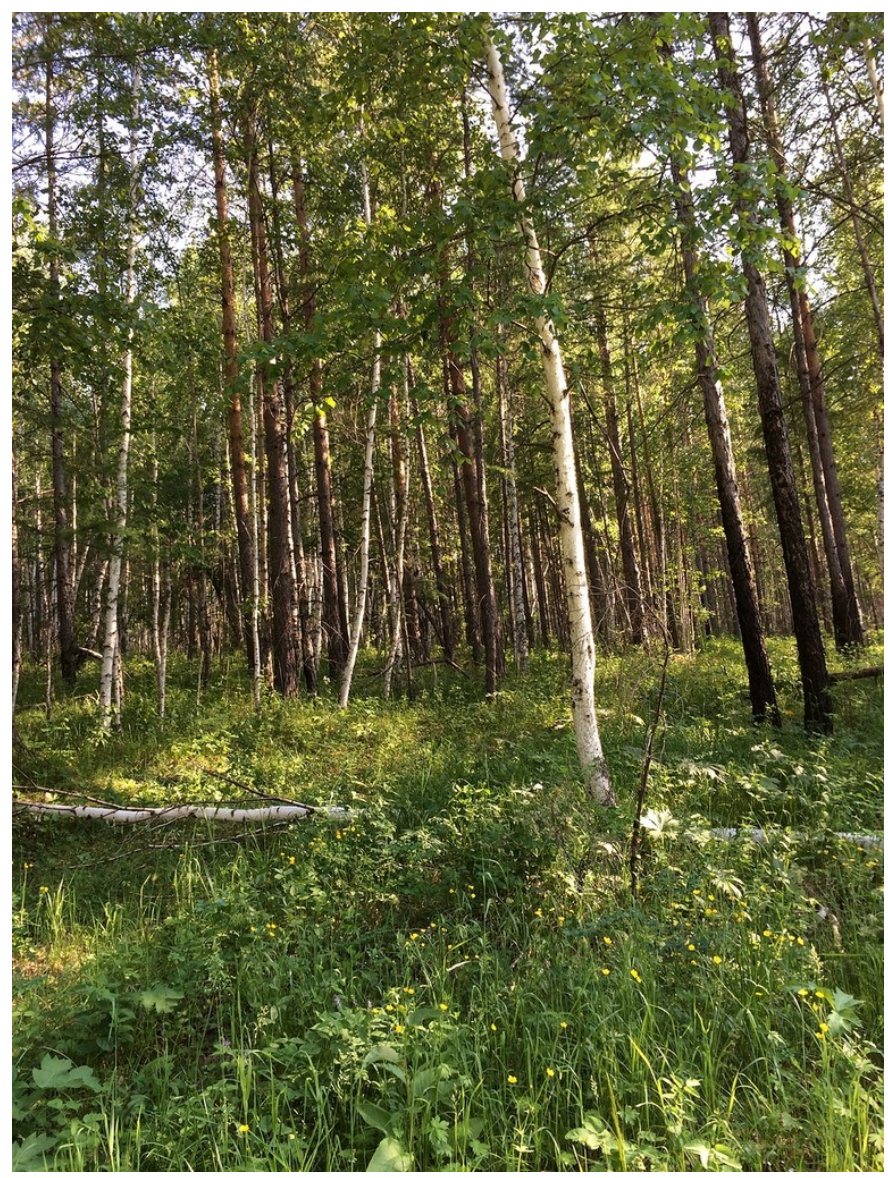

Figure 2. Birch (Betula pendula Roth)—pine (Pinus sylvestris L.) forests with motley grasses at graded slopes. 


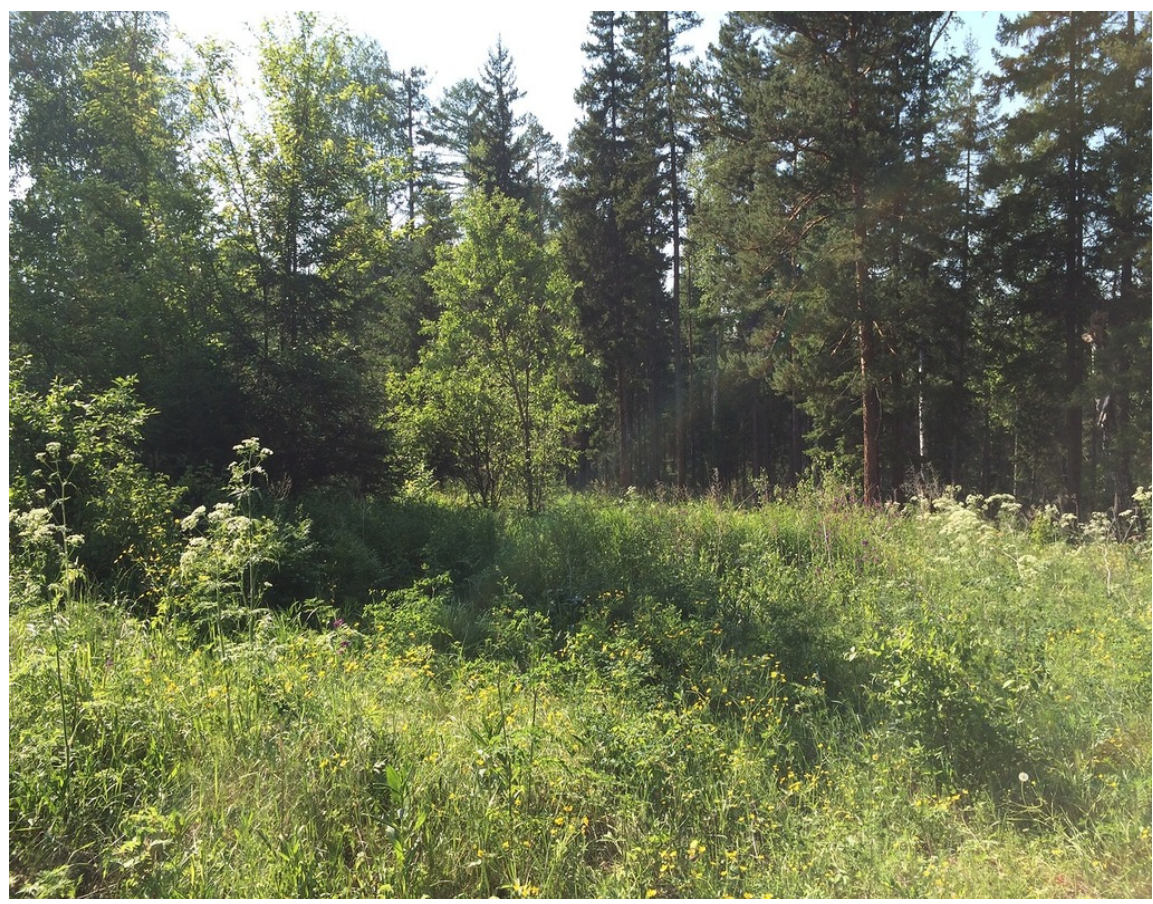

Figure 3. Pine (Pinus sylvestris L.) forests with inclusions of birch (Betula pendula Roth.), cowberry (Vaccinium vitis-idea L.) and motley grasses at the bottoms of graded slopes.

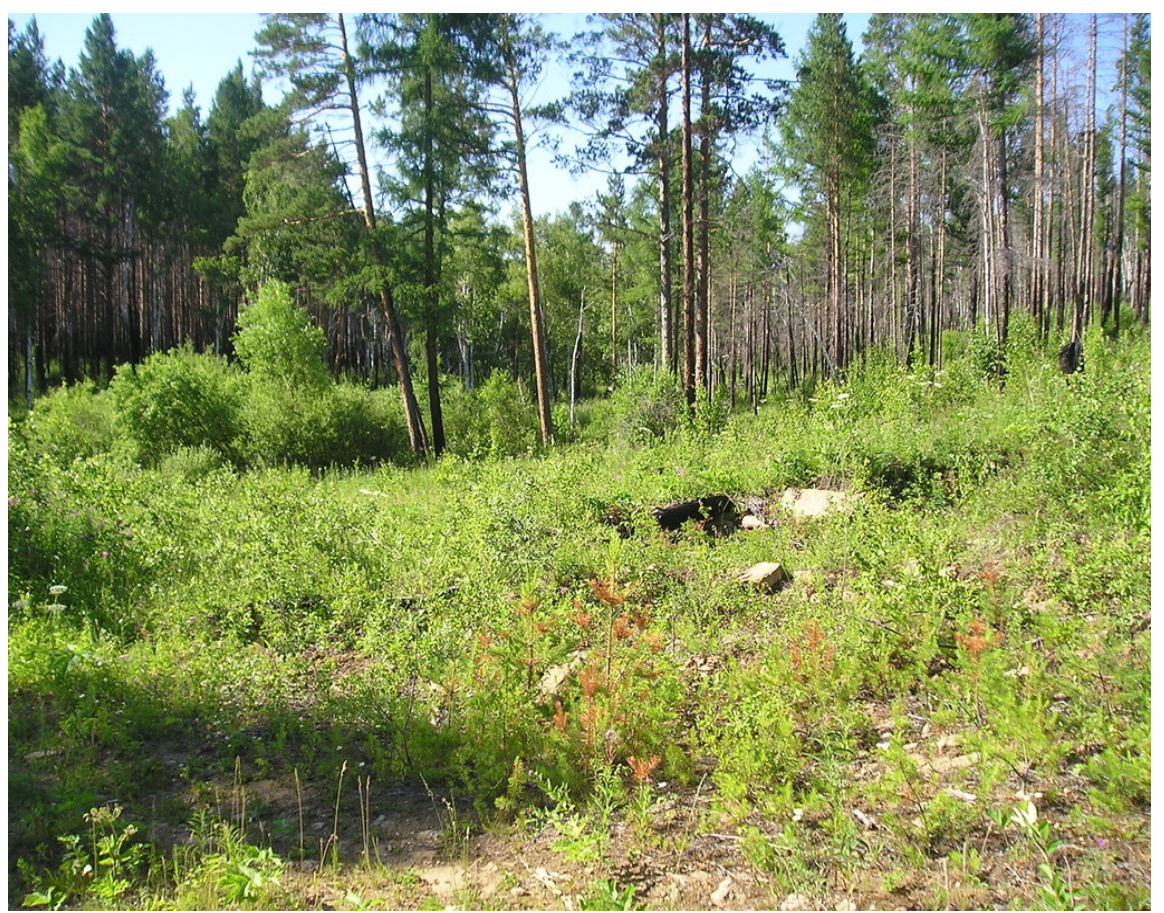

Figure 4. Pine (Pinus sylvestris L.) forests of different age (pine timber stand varies from 80 to 120 y.o. in the first synfolium; up to $40-50$ y.o. in the second synfolium (very rarely); there are very few trees aged from 5 to 15 - 25 y.o. due to frequent fires during different years; at some sites, especially at ones of total cutting, there are pines up to 2 - 3 y.o. with undergrowth up to 10 y.o.) with motley grasses surrounded by old forest cuts where undergrowth of pine (Pinus sylvestris L.) and birch (Betula pendula Roth) is formed. 


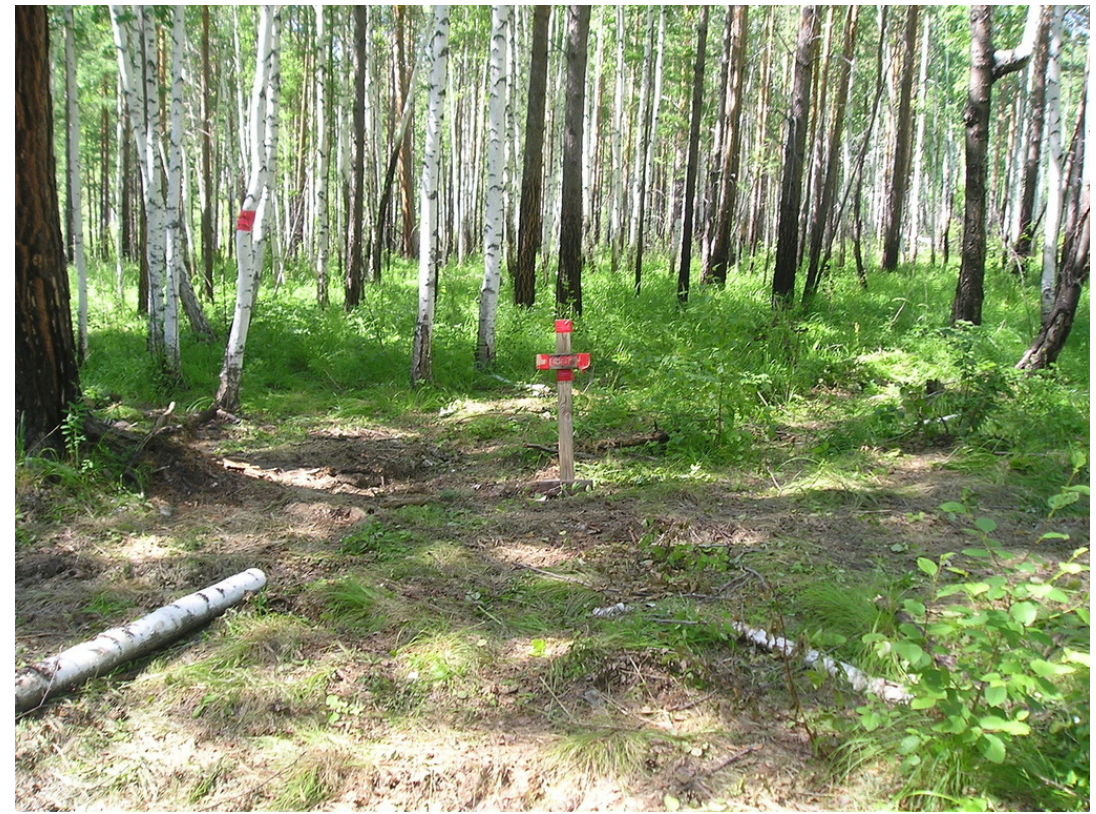

Figure 5. Second growth of birch (Betula pendula Roth.) with inclusion of pine (Pinus sylvestris L.) with pine timber stand varies from 80 to 120 y.o. in the first synfolium and there are pines up to 2 - 3 y.o., just very rarely by fire reason, sedge (Carex macroura Meinsh.)-and motley grasses at true surfaces.

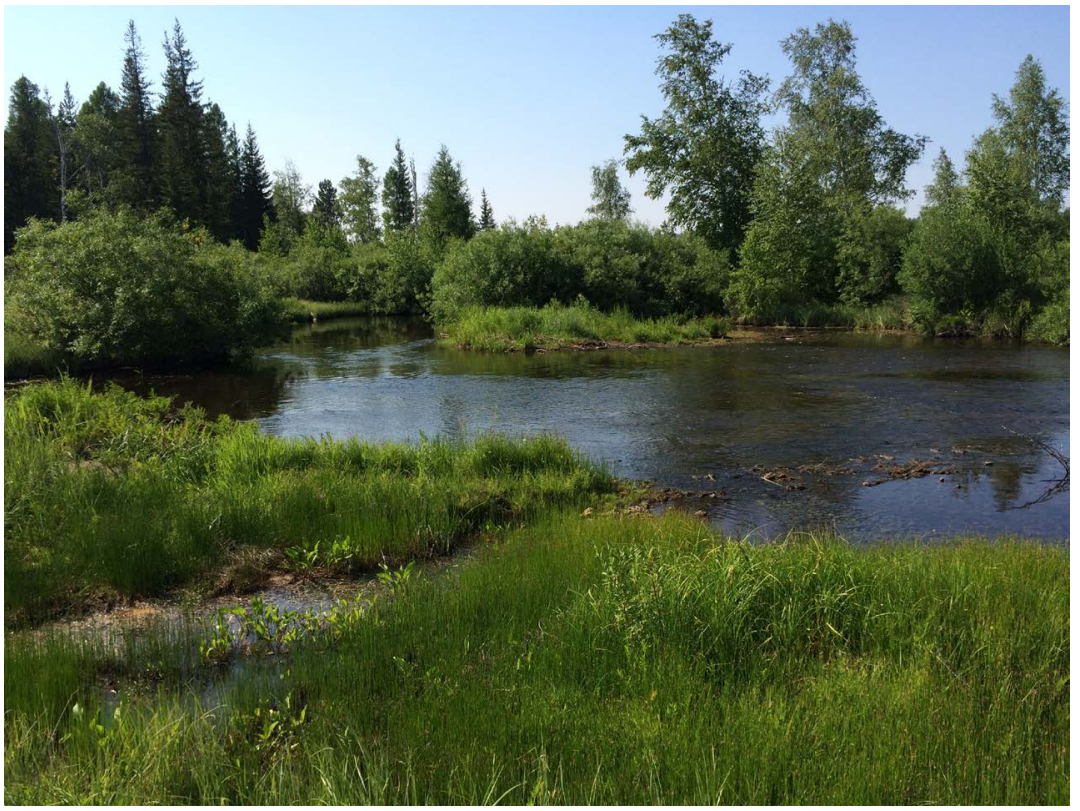

Figure 6. Larix (Larix sibirica Ledeb.)—spruce (Picea obovata Ledeb.) shrubby forests with sedge and motley grasses at low terraces above the flood plains, rarely swampy.

(Betula pendula Roth). This suggests a primary stage of reconstitution of polydominant larch-pine forests with birch inclusion everywhere.

There are abundant second forests of birch (Betula pendula Roth.) with motley grasses and inclusions of pine (Pinus sylvestris L.) and with a very rare undergrowth consisting mainly of birch ((Betula pendula Roth.). The soil cover is 
formed of overgrowth of small reed (Calamagrostis neglecta (Fhrh.) Gaertner, Meyer et Scheber) with sedge (Carex macroura Meinsh.) and forest motley grasses as Veratrum lobelianum Bernh., Paris quadrifolia L., Iris ruthenica KerGawler, Dianthus versicolor Fisch. ex Link, Aconitum barbatum Pers., Anemonoides reflexa (Steph.) Halub., Aquilegia sibirica Lam., Atragene sibirica L., Pulsatilla multifida (Z. Pritzel) Juz., Trollius asiatica L., Sanguisorba officinalis L., Lathyrus humilis (Serg.) Spreng., Lupinaster pentaphyllus Moensh, Vicia cracca L., Geranium wlassavianum Fiisch. ex Link, Geranium sibiricum L., Carum carvi L., Pulmonaria mollis Wulfen ex Hornem., Achillea asiatica Serg., Antennaria dioca (L.) Gaerth., Scorzonera radiata Fisch., Tanasetum vulgare L., Cacalia hastata L., Crepis sibirica L., Hieracium umbellatum L.(see Figure 5).

On the banks of water flows, main vegetation consists of larch (Larix sibirica Ledeb.)-spruce (Picea obovata Ledeb.), often shrubby (Salix caprea L., Salix hastata L.) motley grasses (Angelica anomala Ave-Lall., Heracleum dissectum Ledeb.)-sedge (Carex rhynchophysa C.A. Mey, Carex acuta L., Carex meyeriana Kunth, Carex shmidtii Meinsh.) communities developing sustainably due to a high resistance of habitats for a long time (Figure 6).

At the former burnt-out forests (Figure 7) and along roads, second growth is formed. It consists of birch (Betula pendula Roth.) with inclusion of pine (Pinus sylvestris L.), often with birch undergrowth. Soil cover mainly consists of sally-bloom (Chamaenerion angustifolium (L.) Scop.), small reed (Calamagrostis neglecta (Fhrh.) Gaertner, Meyer et Scheber) and forest motley grasses with inclusion of sedge (Carex macroura Meinsh.) characteristic for small-leaf forests under such development conditions (Figure 8).

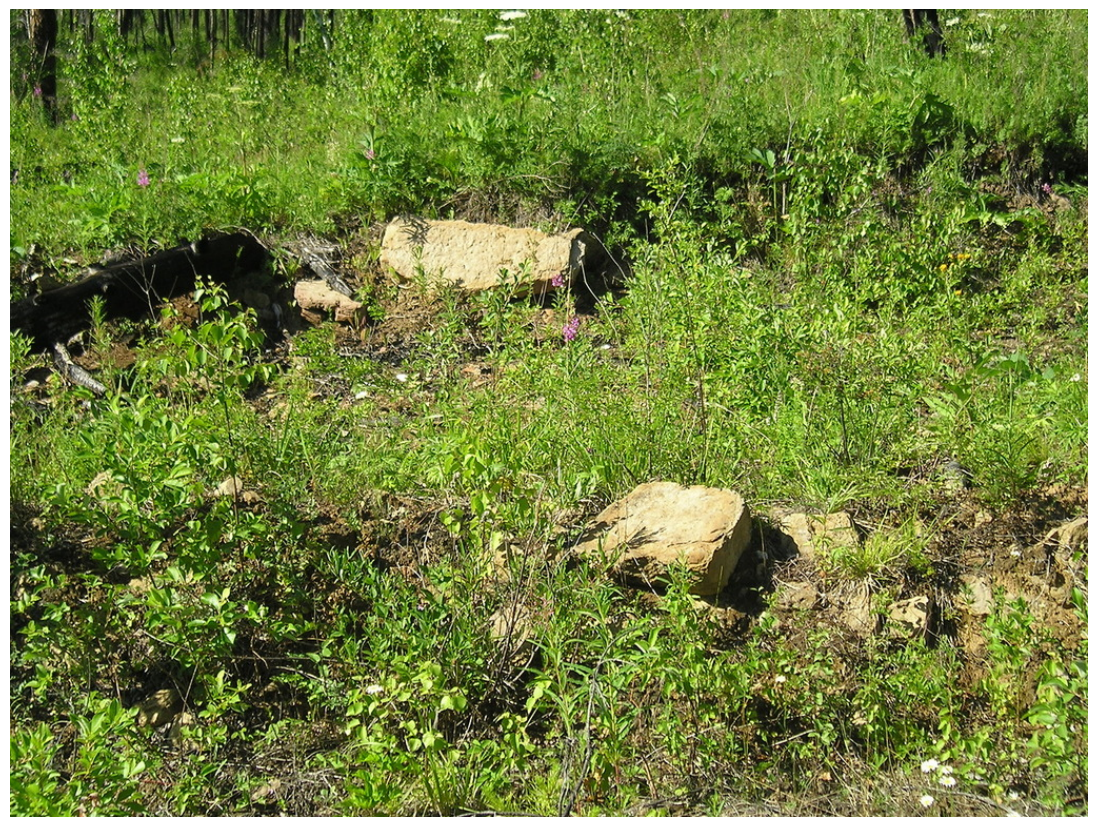

Figure 7. Rare undergrowth of pine (Pinus sylvestris L.) with birch (Betula pendula Roth.) young growth at the site of burnt-out forests with pine, cowberry (Vaccinium vitis-idea L.) and motley grasses of the graded slopes. 


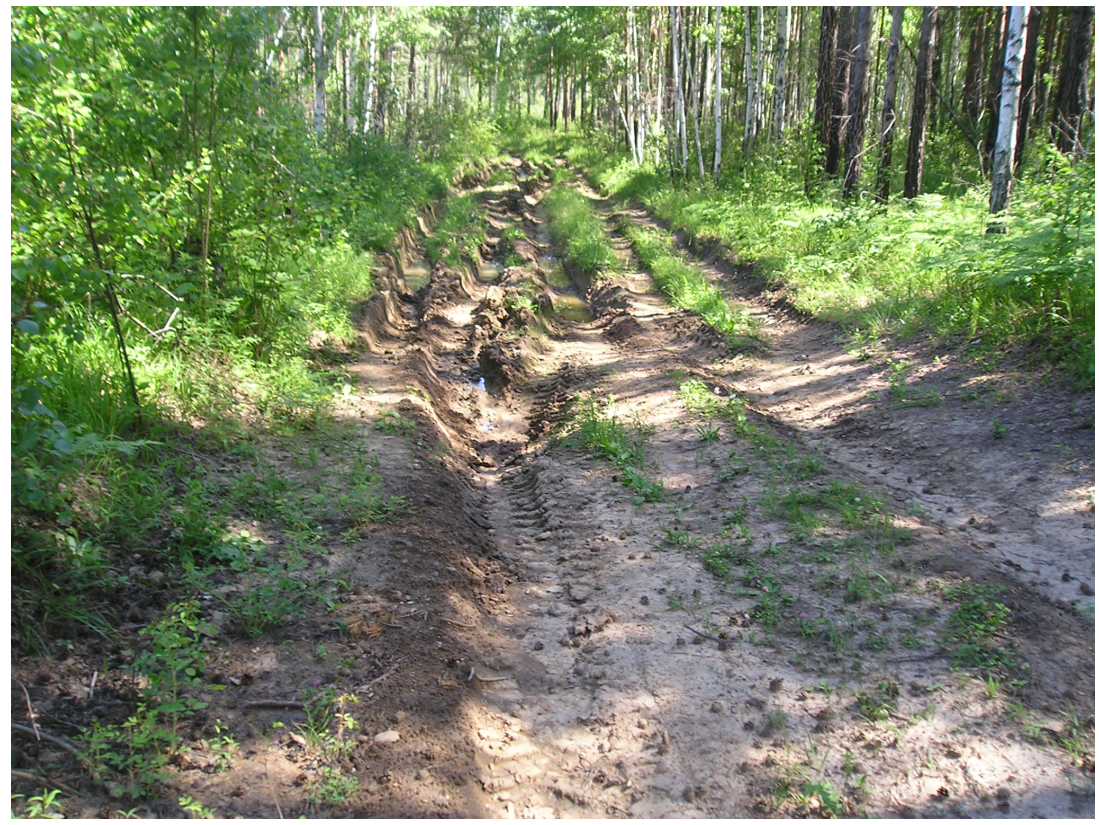

Figure 8. Second growth of birch (Betula pendula Roth.) with inclusion of pine (Pinus sylvestris $\mathrm{L}$.) and motley grasses along the transport communications at the studied territory.

Due to the performed studies, we obtained data on the modern state of the phytocenoses in the studied area and in its surroundings. A considerable part of the territory is occupied by second growth forests containing pine, birch and grasses of reconstitutional series; this is characteristic for vegetation of subtaiga type with small sites of meadows and forests in low terraces above flood plains, where larch-spruce shrubby, rarely swampy forests of riverine valleys are formed.

\section{Conclusion}

According to the recommendations [1] [2] and data resulting from the studies of modern state of vegetation on the territory reserved for a coal mine, the area can be used for such purposes. The information of the structure of phytocenoses modern state can be a reference position for the assessment of a possible impact of technical activities on the state of phytocenoses around the territory of the mine establishment. At the same time, it can serve a base of forecast models of the development of vegetation under the condition of technogenic impact of this area of Irkutsk Region as a whole.

\section{References}

[1] Vorobyov, V.V., Ed. (1988) Map of Land Use in the South of the East Siberia. Head Department of Geodesy and Cartography, Moscow, 2 Sheets.

[2] Snytko, V.A., Ed. (2002) Ecological Zoning of Baikalian Natural Area. Map (Scale 1: 1000 000). Institute of Geography of RAS SB, Irkutsk, 2 Sheets.

[3] Sochava, V.B., Ed. (1977) Correlational Ecological-Phytocenotic Map. (Scale 1: 
7500 000). Institute of Geography of Siberia and Far East, Irkutsk, 1 Sheet.

[4] Belov, A.V., Ed. (2004) Atlas of Irkutsk Region. Vegetation. Map (Scale 1: 2500 000). Irkutsk: Institute of Geography of RAS SB, 1 Sheet (page 42).

[5] Sochava, V.B., Ed. (1972) Vegetation of the South of the East Siberia. Map (Scale 1: 1500 000). Head Department of Geodesy and Cartography, Moscow, 4 Sheets.

[6] Kolisnichenko, V.T. and Ufimtseva, K.A., Eds. (1988) Map of Soils of Irkutsk Region (Scale 1: 1500 000,). Head Department of Geodesy and Cartography, Moscow, 2 Sheets.

Submit or recommend next manuscript to OALib Journal and we will provide best service for you:

- Publication frequency: Monthly

- 9 subject areas of science, technology and medicine

- Fair and rigorous peer-review system

- Fast publication process

- Article promotion in various social networking sites (LinkedIn, Facebook, Twitter, etc.)

- Maximum dissemination of your research work

Submit Your Paper Online: Click Here to Submit

Or Contact service@oalib.com 